\title{
The Determination of Concentration and Type of Ownership on Bank Performance and Risks in Indonesia
}

\author{
Yacobo P. Sijabat 1,*(D), Michael Jeffri Sinabutar 2, (D), Heni Hirawati 1, (D), \\ and Axel Giovanni ${ }^{1}$ \\ ${ }^{1}$ Department of Management, Faculty of Economics, \\ Tidar University, 56116, Magelang, Indonesia \\ 2 Department of Sociology, Faculty of Social and Political Sciences, \\ University of Bangka Belitung, 33172, Bangka Belitung Islands, Indonesia \\ * Corresponding Author: yacobo.djabat@untidar.ac.id
}

\begin{tabular}{|l|}
\hline ARTICLE INFO \\
\hline $\begin{array}{l}\text { Publication Info: } \\
\text { Literature Review }\end{array}$ \\
\hline $\begin{array}{c}\text { check for } \\
\text { updates }\end{array}$ \\
\hline
\end{tabular}

How to cite:

Sijabat, Y. P., Sinabutar, M. J.,

Hirawati, H., \& Giovanni, A.

(2020). The Determination of

Concentration and Type of

Ownership on Bank Performance

and Risks in Indonesia. Society,

8(1), 151-163.

DOI : 10.33019/society.v8i1.152

Copyright $\odot$ 2020. Owned by Author(s), published by Society

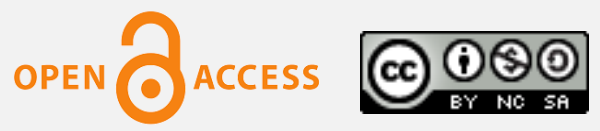

This is an open-access article.

License: Attribution-

NonCommercial-ShareAlike (CC BY-NC-SA)

\section{ABSTRACT}

This research aims to examine the determination of concentration and type of ownership on the performance and risks of banks listed on the Indonesia Stock Exchange (IDX) for the period 2000-2018. This research was quantitative research using panel data regression analysis methods. The main characteristic of panel data regression analysis is the use of the Hausman test. Data were obtained and collaborated from several data providers such as Osiris, Bloomberg, and the Financial Seroices Authority (Otoritas Jasa Keuangan or OJK) website. Secondary data were collected from 42 banks listed on the Indonesia Stock Exchange (IDX) using a purposive sampling technique. The data was processed using Stata software. The ownership concentration was measured using the Herfindahl-Hirschman Index (HHI) and foreign and domestic ownership as the proxy using the dummy variable. To measure bank performance, this research was used ROA and ROE proxy while the standard deviation of returns was used to measure bank risks. The results of the research showed that there was no effect of ownership concentration on bank performance. Also, domestic ownership has a positive effect on bank performance. In terms of risks, ownership concentration has a positive effect on bank risks. The more concentrated the ownership of the bank, the bank will more at risks. Besides, foreign and domestic ownership affects bank risks. Foreign ownership has a positive effect on bank risks. The level of foreign ownership of the bank affects bank risks. High foreign ownership puts the bank at risk. 
Received: February 20, 2020;

Accepted: April 6, 2020;

Published: June 30, 2020;
Keywords:
Bank; Domestic;
Performance; Risk
Foreign;
Ownership;

\section{Introduction}

Since early July 1997, Indonesia has been hit by the monetary economic crisis. The crisis was getting worse and became a multidimensional crisis, not only in the economic field but also in the political and social fields. The monetary economic crisis was hit the national economy. Many companies went bankrupt and large numbers of workers lost their jobs. The number of unemployed and poor people was increasing rapidly. The crisis in 1998 has become a dark history of Indonesia. The severe crisis at that time was not only caused by the monetary economic crisis. Various national disasters, which occur continuously in difficult economic periods such as the failure of the rice harvest in several rice-producing areas due to the long and worst drought in the last 50 years, pests, massive forest fires in Kalimantan and riots that hit many cities in mid-May 1998 and many other disasters. The crisis also hit Indonesian banks, which have a weak banking system.

In terms of good governance, performance and risks are closely related to the management. The performance of domestic banks or foreign banks depends on the ability of management to manage the banks. Also, bank ownership contributes to bank performance and risks. The owner can control the management through the commissioner as their representative. The owner chooses and appoints professional managers to manage the company. Bank owners, like other companies, always want a return on their investment. The owner will encourage the management to optimize the bank's resources to produce maximum profit. The ultimate goal of bank management is to get a profit that is reflected by the bank's performance. The bank owner will choose the right management which can manage the bank properly and profitably. In general, bank owners strongly avoid bank losses.

Banks in Indonesia have very diverse ownership. Before the peak period of the crisis in 1998, the government issued policies and strategies to involve or enhance the role of the private sector in national development. The government has carried out deregulation and debureaucratization in the financial and banking sectors to support large funds for national development. One of the objectives of deregulation and debureaucratization policies is to develop the banking system healthier, more efficient, and more resilient (Bank Indonesia, 2007). The initial phase of banking deregulation began in 1983, including the elimination of credit limits, banks are free to set interest rates on loans, savings, deposits, and stop the Bank Indonesia Liquidity Credit (Kredit Likuiditas Bank Indonesia or KLBI) program to all banks except for certain types of loans, which are related to cooperatives and exports. The policy had a positive impact on the financial and banking sectors. Private banking begins to rise and grow and can determine the direction of the development of the bank's business. The initial stage of deregulation succeeded in increasing competition among banks. The banking deregulation policy increases investment credit to the industrial sector due to easy banking loan application rules. However, the deregulation did not always make positive changes. The early 1990 period showed that there were many non-performing loans involving entrepreneurs in Indonesia. Banking deregulation policies can deviate from the original goal due to the behavior of entrepreneurs who use credit facilities without strict control. Private capital flow in large numbers to the banking sector is another impact of banking deregulation policies. During the 1998 crisis, the banking system was hit and underwent many policy changes. The main factor at that time was the occurrence of the global crisis, especially in the Southeast Asian region. Also,

Copyright ( ) 2020. Owned by Author(s), published by Society. This is an open-access article under the CC-BY-NC-SA license.

https://doi.org/10.33019/society.v8i1.152

192 
banking deregulation policies in Indonesia are not carried out with good banking risk management. The impact of the crisis had given a bad sentiment for bank and non-bank financial institutions in Indonesia. The Bank trust level has dropped drastically, both by the domestic and foreign communities. The panic of domestic bank customers increased and considered that saving funds in banks was no longer safe. The Indonesian economic collapse and affected all sectors. The government reforms the banking sector first to overcome this crisis. The government implemented a banking reform policy in March 1999 by closing 7 banks and instructed 73 banks to maintain their operations without recapitulation. In 2001, there were 151 banks still operating (Dewayanto, 2010).

Therefore, aside from discussing regulations, it is really necessary to research banking ownership. Research on the structure of bank ownership is very interesting to examine the effect of bank ownership on bank performance and risks. This is based on the authority of the bank's owner to choose the management to manage the bank which will further determine the bank's policy to achieve its objectives.

The bank owner is usually more than one person. The ownership structure of each bank varies from the level of ownership concentration and the type of bank ownership. Considering the importance of the relationship between the ownership structure and bank management, it is necessary to study this relationship in-depth if the ownership of the bank has a variety of types and backgrounds and different levels of concentration. The level of concentration of bank ownership has an impact on bank performance and risks. Shareholders, with large shareholdings, affect the character of a company in risks (Wright et al., 1996 as cited in Chun et al., 2011). Bank ownership, in large numbers (dominant), by a person or group tends to implement a conservative investment policy in anticipation of risks that will occur due to large ownership (Paligorova, 2010). The concentrated ownership (proxied with various levels of shareholders) significantly reduced the ratio of non-performing loans, with arrangements related to shareholder protection and control. Furthermore, ownership concentration affects the capital adequacy ratio positively. The ownership concentration can reduce the bank's risk at low levels of shareholder protection and control (Shehzad et al., 2010 as cited in Ahmad, 2013). Apart from the concentration of bank ownership, the diversity of types of ownership such as state-owned banks, private national banks, and foreign banks needs to be further examined with the performance of each bank. Bank ownership by diversity shareholders type compared to bank ownership by other types of shareholders needs to be measured to see the level of difference in performance based on the type of bank ownership. Foreign ownership in a company is often related to higher internal corporate governance and control to ensure the management of the company is controlled and in line with the interests and long-term goals. It also relates to capital capacity and better resource capabilities in managing risks and conducting business effectively. Foreign banks are often related to good bank performance and higher profitability (Chen \& Liao, 2011 as cited in Demirhan, 2013; Nguyen, 2012) and strongly correlated with good performance for developing countries (Micco et al., 2007 as cited in Ahmad, 2013; Chen \& Liao, 2011 as cited in Demirhan, 2013). The results of research conducted by Chen \& Liao, 2011 as cited in Demirhan, 2013 found that foreign banks from 12 other countries, including Indonesia, had relatively better performance than domestic banks. The research also showed that foreign ownership has an impact on increasing risk-taking (Nguyen, 2012). To obtain high business returns and have better resources, foreign banks will carry out high-risk business activities.

Other assumptions from previous research, which are concluded from this relationship, indicate the possibility that the structure of bank ownership is not related to the bank's

Copyright ( ) 2020. Owned by Author(s), published by Society. This is an open-access article under the CC-BY-NC-SA license. https://doi.org/10.33019/society.v8i1.152 
performance at all. The results of research conducted by Barth et al., (2000) using data from 60 countries concluded that bank ownership by non-financial institutions is not related to the performance of the bank. A large number of state-owned banks tend to slow the development of bank performance. Research conducted by La Porta et al., (1999) as cited in Saggese \& Sarto (2016) also examined the effect of state-owned on bank performance. The research used alternative measures of bank ownership and examined the relationship between state-owned and financial development. The results showed that state-owned banks slowed developments in the financial sector. The research conducted by Hadad et al., (2004) using empirical data on 131 banks in Indonesia concluded that bank performance has no relation with bank ownership. Research conducted by Al-Amarneh (2014) on ownership structure and bank performance, concluded that in profitability ratios, ownership concentration has a positive and significant effect on bank performance. While in the operational efficiency ratio, foreign ownership has a positive effect on bank performance. The results of research conducted by Boussaada \& Karmani (2015) explained significant differences in the level of bank performance in the Middle East and North Africa (MENA) region. Banks with large foreign shareholdings tend to produce high levels of bank performance. Meanwhile, state-owned banks tend to have a negative relation with bank performance.

These assumptions certainly need to be deepened further with in-depth research using empirical data. Research that uses ownership concentration variables and ownership types that are related to the company or bank performance has often been conducted. However, research that collaborates on the company or bank performance and risks is still very rare. This research adds the variables of bank risks, referring to the Indonesian banking system in the period before, during or after the monetary economic crisis. Based on the information obtained, the structure and type of bank ownership and the unique condition of the banking system during the Indonesian political, economic and social turmoil are very relevant for research. Also, the operation of various types of banks with different structures and types of ownership as well as the many changes in ownership due to several conditions that occurred in Indonesia such as the 1998 and 2008 crises. Therefore, this research aims to examine the concentration and type of bank ownership in Indonesia.

\section{Literature Review}

The structure and concentration of ownership have a difference in each country. There is a diversity of approaches to the concentration of ownership among developing countries, developed countries, and countries that are in transition. The structure of shareholders ownership shows the distribution of power and the role of shareholders in the company's operational activities. In a business entity, share ownership consists of 2 types, consisting of (a) Dispersed Ownership, and (b) Concentrated Ownership (Closely-Held). Concentrated ownership is a condition where most shares are owned by a small number of individuals or groups (dominant shareholders). In the type of concentrated ownership, there are two groups of shareholders, consisting of (1) controlling interest (dominant shareholders), and (2) minority interest (non-controlling interest/minority shareholders). The large shareholders have an important role in monitoring the management activities of a business entity (Shleifer \& Vishny, 1997 as cited in Ahmad, 2013). Large shareholders such as institutional investors will be able to monitor management more intensively. Based on the research results of La Porta et al., (1998, 2000) as cited in Anggraini et al., (2015) found that the French origin countries group (including Indonesia) had the highest concentration of ownership compared to the three other origin countries groups. In the sample group, even Indonesian companies showed that ownership

Copyright ( $(2020$. Owned by Author(s), published by Society. This is an open-access article under the CC-BY-NC-SA license. https://doi.org/10.33019/society.v8i1.152

194 
concentrations greater than the average group are the three largest shareholders with average share ownership of $58 \%$. Lack of legal protection and the institutional environment (law enforcement) are closely related to concentrated ownership. Whereas dispersed ownership is a condition where the ownership of the shares is distributed equally to the public, there is no large shareholder. The concentration of ownership becomes an internal mechanism for management discipline, which is used for monitoring effectiveness. In a dispersed ownership structure, conflicts usually occur between management and shareholders. Small investor shareholding is not very effective in monitoring management performance. As a consequence, a great responsibility lies with management. The impact, the emergence of large salary demands from management. To reduce this conflict, agency costs are needed for salary arrangements, various facilities or are involved in managerial ownership.

In developed economies, the patterns of dispersed ownership can increase market efficiency. This is because the rules and regulations have been implemented properly and regularly (Satya, 2007). But it is different from what happens in developing countries. Research conducted by Grossman \& Hart (1980) as cited in Dalkir et al., (2019) stated that there is a possibility that agency costs will increase in dispersed ownership (low ownership concentration). The management has the opportunity to conduct expropriation as a result of weak monitoring from shareholders due to the existence of asymmetric information in dispersed ownership. Low ownership concentration also encourages free-rider problems where each shareholder relies on management control efforts on other shareholders. Because it is adapted to the conditions of Indonesia which is a developing country, and based on the results of previous researches conducted by Prowse (1992) as cited in Al-Amarneh (2014), Imam \& Malik (2007) and Shleifer \& Vishny (1997) as cited in Ahmad (2013), this research will conduct testing with the following hypothesis:

\section{$H_{1}$ Ownership concentration has a positive effect on the bank's performance.}

The results of previous researches showed that the type of bank ownership will have an impact on the management system and different potential risks. Thus, directly or indirectly, it will affect bank performance and risks. There is a difference between foreign ownership in developed countries and foreign ownership in developing countries. The results of research on foreign ownership are also very varied, such as research conducted by Tandelilin et al., (2007) as cited in Demirhan (2013), Imam \& Malik (2007), and Kim \& Lyn (1990) as cited in Hintošová \& Kubíková (2016). This is due to the different conditions, objectives, and investment approaches in each country that affects the company's performance in each country. Chen \& Liao (2011) as cited in Demirhan (2013) conducted research to test whether foreign banks in developing countries were more productive than domestic banks. The results showed that competition from foreign banks forced domestic banks to become more efficient. Domestic banks learn a lot and imitate the operational capabilities of foreign banks thereby increasing the productivity of domestic banks. This process is easier for countries with rapid economic development. Dinh (2013) as cited in Phung \& Tröge (2018) conducted research to examine the profitability of foreign banks compared to domestic banks operating in Vietnam. The results showed that foreign banks performed better than domestic banks due to large investments in technology and efficient risk management. Deregulation contributed to the success of foreign banks to compete with domestic banks. Based on some of the arguments and facts above, this research formulates the hypothesis as follows:

$\mathrm{H}_{2}$ Foreign ownership has a positive effect on financial performance. 
$H_{3}$ Domestic ownership has a negative effect on financial performance.

The concentration of ownership can also affect the risk of a company (risk-taking). Wright et al., (1996) as cited in Chun et al., (2011) stated that large shareholders affect the character of a company in risk-taking, competing, and surviving. Based on some of the arguments and facts above, this research formulates the hypothesis as follows:

\section{$H_{4}$ Ownership concentration has a positive effect on bank risks.}

Risk is also influenced by the type of ownership both foreign and domestic. Research conducted by Barry et al., (2011) as cited in Ahmad (2013) divided five categories of ownership structure consisting of (1) ownership structure by individuals or families, (2) institutional investors, (3) managers, (4) non-financial companies, and (5) bank. The results of the research showed that diverse ownership structures have significant effects on bank risk-taking behavior. Saunders et al., (1990) as cited in Ahmad (2013) found that managers who also own shares in the bank will affect the decline in bank risk-taking. Other types of ownership that influence bank risk-taking is the state-owned bank, private national bank (domestic banks), and foreign banks. Research conducted by Nguyen (2012) showed that high levels of foreign ownership will increase risk-taking conducted by management. Research conducted by Dinh (2013) as cited in Phung \& Tröge (2018) to examine the profitability of foreign banks compared to domestic banks operating in Vietnam, showed that the performance of foreign banks is better than domestic banks due to large investments in technology and efficient risks management. This is in line with the impact of the development or progress of the times. Humans, with science and technology, will try to find innovations to make things easier. Foreign banks often related to better management, innovation, higher return expectations, and encourage higher risk-taking. Foreign banks are also related to large organizations, high human resource competencies, and experienced expatriates in the financial services sector (Chen \& Liao, 2011 as cited in Demirhan, 2013). Foreign banks have much higher control capabilities, better corporate governance, and can manage bank risks to obtain high returns. Banking is a financial sector that plays a role in driving the wheels of the economic growth of a country. People with excess funds can save their money in the bank. People who need funds can apply for bank loans. The concept of sociology, homo homonicus, humans are inherently social. Humans cannot live alone and need each other. This concept is applied in banking.

This is very important because the concept of mutual assistance within the community is the main thing. At present, a process of national economic recovery is urgently needed. The function of banks as intermediaries is very important. However, since the monetary economic crisis, the Indonesian national banking system has faced quite serious problems. This is indicated by the increasing number of non-performing loans, the deterioration of net interest income and capital problems, as well as the threat of liquidity problems that continue to present. Also, the level of public trust in the domestic and foreign banks still varies due to the traumatic effects of the multi-dimensional crisis in 1998. Based on some of the arguments and facts above, this research formulates the hypothesis as follows:

$H_{5}$ Foreign ownership has a positive effect on bank risks.

$H_{6}$ Domestic ownership has a positive effect on bank risks.

Copyright $($ 2020. Owned by Author(s), published by Society. This is an open-access article under the CC-BY-NC-SA license. https://doi.org/10.33019/society.v8i1.152

196 


\section{Research Methodology}

This research was quantitative and conducted in April - November 2019. This research was using panel data regression analysis methods. The main characteristic of panel data regression analysis is the use of the Hausman test. Data were obtained and collaborated from several data providers such as Osiris, Bloomberg, the Financial Services Authority (Otoritas Jasa Keuangan or OJK) website, annual financial reports, and publication reports. Secondary data were collected from 42 banks listed on the Indonesia Stock Exchange (IDX) from 2000-2018 and regularly publishes bank financial statements for 5 consecutive years, using a purposive sampling technique.

There are two dependent variables in this research, consisting of (1) bank performance, and (2) bank risks. First, bank performance variables use ROA (Return on Assets) and ROE (Return on Equity). The researches conducted by Demirgüç-Kunt \& Huizinga (2000) as cited in Boussaada \& Karmani (2015), Claessens et al., (2001) as cited in Boussaada \& Karmani (2015), and Mahajan et al., (2012) as cited in Boussaada \& Karmani (2015) used the same variable in measuring bank performance. Second, the bank risks variables measured by the standard deviation of returns or coefficient variation of returns. Research conducted by Pathan (2009) and Niu (2012) used the same variable in measuring total risk.

There are two independent variables in this research, consisting of (1) concentration of bank ownership, and (2) type of bank ownership. First, the ownership concentration variable, which is a benchmark for the distribution of bank ownership, will be measured using the HerfindahlHirschman Index (HHI). Similar methods are also used in research conducted by Pham et al., (2003), and Céspedes et al., (2010). The Herfindahl-Hirschman Index (HHI) formula is as follows:

$$
H H I=\sum_{i=1}^{n} S_{i}^{2}
$$

Second, the ownership type variables consisting of (1) foreign proxy, and (2) domestic proxy (Al-Armaneh, 2014). Foreign ownership proxy was given a value of 1 if the majority of shares were owned by foreign investors and a value of 0 for the others. Whereas in the proxy for domestic ownership (state-owned) is given a value of 1 if the majority of shares are owned by domestic investors (state-owned), and a value of 0 for the others.

The Control Variables in this research are Non-Performing Loans Ratio (NPL), Capital Adequacy Ratio (CAR), Net Interest Margin (NIM), BOPO, Loan to Deposit Ratio (LDR), and Company Size (Ln Total Assets).

This research used panel data regression analysis techniques, which have previously been carried out several tests, consisting of heterogeneity and multicollinearity tests. A multicollinearity test is used to find out the linear correlation deviation between independent variables in the regression analysis. Heteroscedasticity is the variance inequality of residuals from one observation to another. Regression models, which are following BLUE (Best Linear Unbiased Estimators) requirements, are regression models with fixed residual variants from one observation to another (homoscedasticity).

Multicollinearity occurs if there is a correlation between one or more independent variables in the regression model. The data processing used Stata 13 software. After being fulfilled, then the best model selection is tested. Regression using panel data will produce different intercepts and slopes for each individual (company) and each period (year). The test used is the Hausman test, which tests and chooses the fixed-effect method or the random effect method. 
Furthermore, the hypothesis test was carried out using the $t$ test and the $F$ test. The $t$ test was to test the effect of the independent variables individually on the dependent variable and the control variable with $a<0.05$. The $F$ test was to test the independent variables and control variables in the aggregate of the dependent variable with $a<0.05$.

The equation method:

$$
\begin{aligned}
& \text { Performance }_{i, t}=\beta_{1}+\beta_{2} \text { Constration }+\beta_{3} \text { Control Variable }+\varepsilon_{i t} \\
& \text { Performance }_{i, t}=\beta_{1}+\beta_{2} \text { dummyforeign }+\beta_{3} \text { Control Variable }+\varepsilon_{i t} \\
& \operatorname{Risk}_{i, t}=\beta_{1}+\beta_{2} \text { Constration }+\beta_{3} \text { Control Variable }+\varepsilon_{i t} \\
& \text { Risk }_{i, t}=\beta_{1}+\beta_{2} \text { Constration }+\beta_{3} \text { Control Variable }+\varepsilon_{i t}
\end{aligned}
$$

Table 1. Descriptive statistics of research data for each variable

\begin{tabular}{|l|c|c|c|c|}
\hline Description & Mean & Min & Max & Std. Dev. \\
\hline Dependent Variables & .0205642 & -1.5492 & .2659 & .0979446 \\
\hline ROA & .1609531 & -7.6136 & 4.0286 & .4950814 \\
\hline ROE & 4.853406 & .8953977 & 35.56624 & 4.176185 \\
\hline Total Risk (std. dev. return) & .4971472 & .0492306 & 1 & .2285383 \\
\hline Independent Variables & .1723602 & 0 & 1 & .3779868 \\
\hline Ownership Concentration (HHI) & .8276398 & 0 & 1 & .3779868 \\
\hline Foreign & \multicolumn{5}{|l|}{} \\
\hline Domestic & .0826112 & .0005 & 1.8318 & .1689163 \\
\hline Control Variables & .4683741 & -.3984 & 32.3551 & 1.73726 \\
\hline NPL & .0893015 & -.0641 & 1.261 & .0861061 \\
\hline CAR & 1.347103 & .2068 & 9.9 & .7126598 \\
\hline NIM & 1.064662 & .06 & 9.29 & .5394418 \\
\hline BOPO & 1.212264 & 1.001485 & 1.317253 & .0526654 \\
\hline LDR & 651 & \multicolumn{3}{l|}{} \\
\hline Size & \multicolumn{5}{|l|}{} \\
\hline No of Observation &
\end{tabular}

\section{Results and Discussion}

Based on the data, the ROE variable in Table 1 showed a negative value of -7.6136 . According to the research analysis, this is affected by a large BOPO variable value of 9.9. Furthermore, in-depth research was carried out to find the truth of these values and obtained that they occurred in the 2009 period (1 year after the crisis).

Furthermore, this study tests each hypothesis. Hypothesis testing used panel data regression. A summary of the regression results has been presented in Table 2, Table 3, and Table 4. 
The Determination of Concentration and Type of Ownership on Bank Performance and Risks in Indonesia

Table 2. Regression Results: Performance (ROA) of concentration of ownership, foreign ownership, and domestic ownership

\begin{tabular}{|c|c|c|c|}
\hline Description & $H_{1}$ & $\mathrm{H}_{2}$ & $\mathrm{H}_{3}$ \\
\hline \multicolumn{4}{|l|}{ Independent Variables } \\
\hline Ownership Concentration (HHI) & .0471237 & & \\
\hline Foreign & & $-.0675933^{* * *}$ & \\
\hline Domestic & & & $0675933^{* * *}$ \\
\hline \multicolumn{4}{|l|}{ Control Variables } \\
\hline NPL & -.0135726 & .0004814 & .0004814 \\
\hline CAR & $.0675933^{* * *}$ & $0822291^{* * *}$ & $0822291^{* * *}$ \\
\hline NIM & -.0571829 & -.0659912 & -.0659912 \\
\hline BOPO & $-.1132598^{* * *}$ & $-.1149912^{* * *}$ & $-.1149912^{* * *}$ \\
\hline LDR & $.0979027^{* * *}$ & $.0905375^{* * *}$ & $.0905375^{* * *}$ \\
\hline Size & $-.8786491^{* * *}$ & $-.6415185^{* *}$ & $-.6415185^{* *}$ \\
\hline $\mathrm{R} \mathrm{sq}$ & 0.1767 & 0.2002 & 0.2002 \\
\hline
\end{tabular}

Table 3. Regression Results: Performance (ROE) of concentration of ownership, foreign ownership, and domestic ownership

\begin{tabular}{|c|c|c|c|}
\hline Description & $H_{1}$ & $\mathrm{H}_{2}$ & $H_{3}$ \\
\hline \multicolumn{4}{|l|}{ Independent Variables } \\
\hline Ownership Concentration (HHI) & .1488406 & & \\
\hline Foreign & & -.1711504 & \\
\hline Domestic & & & 1711504 \\
\hline \multicolumn{4}{|l|}{ Control Variables } \\
\hline NPL & -.0253644 & 012682 & .012682 \\
\hline CAR & $.1908854^{* *}$ & .2317913 & 2317913 \\
\hline NIM & $.7281566^{* * *}$ & .7972291 & .7972291 \\
\hline $\mathrm{BOPO}$ & $-.319772^{* * *}$ & -.3260584 & -.3260584 \\
\hline LDR & $.2184414^{* * *}$ & .1994638 & .1994638 \\
\hline Size & $-4.229539^{* * *}$ & -3.683349 & -3.683349 \\
\hline $\mathrm{Rsq}$ & 0.1673 & 0.1813 & 0.1813 \\
\hline
\end{tabular}

Table 2 and Table 3 explain the regression results from hypotheses 1,2, and 3 . In the performance measurement variable, there are two proxies used which consist of ROA and ROE.

In performance measurement using ROA or ROE proxy, performance is not affected by ownership concentration. But on the type of ownership, there is an effect on the performance of foreign and domestic ownership. Based on Table 2 and Table 3, foreign ownership has a negative influence on performance, whether it is measured using the ROA proxy or the ROE proxy. According to research, this is because the performance of several large banks in Indonesia is very good. Large banks in Indonesia are included in the proxy of domestic banks. 
Also, this study analyzes the control variables. This study analyzes the size variable ( $\mathrm{Ln}$ Total Assets) which has a negative effect, with a value (-4.229539), on the two performance variables of each hypothesis. Based on observations and analysis of in-depth research, this is because the size of the bank (size) is filled in the most by credit proxies. The financial statement records credit as an asset. For example, Bank Mandiri in 2016 had total assets of 807,551,112 (in millions), only, more than $50 \%$, around 536,029,812 (in millions) were filled by credit proxies. That causes size (Ln total assets) to have a negative influence on performance.

\section{Table 4. Regression Results: The ratio (std. dev. return) of concentration of ownership, foreign ownership, and domestic ownership}

\begin{tabular}{|c|c|c|c|}
\hline Description & $H_{4}(\mathrm{RE})$ & $\mathrm{H}_{5}(\mathrm{Re})$ & $\mathrm{H}_{6}$ \\
\hline \multicolumn{4}{|l|}{ Independent Variables } \\
\hline Ownership Concentration (HHI) & $4.933365^{* * *}$ & & \\
\hline Foreign & & $2.038534^{* * *}$ & \\
\hline Domestic & & & $-2.038534^{* * *}$ \\
\hline \multicolumn{4}{|l|}{ Control Variables } \\
\hline NPL & $7.334277^{* * *}$ & $8.994565^{* * *}$ & $8.994565^{* * *}$ \\
\hline CAR & .5341653 & .1805981 & .1805981 \\
\hline NIM & -2.815591 & .6136856 & .6136856 \\
\hline BOPO & .3992794 & .3073736 & .3073736 \\
\hline LDR & -.7126571 & -1.091478 & -1.091478 \\
\hline Size & $-38.90649^{* * *}$ & $-39.43775^{* * *}$ & $-39.43775^{* * *}$ \\
\hline $\mathrm{Rsq}$ & 0.3140 & 0.3100 & 0.3100 \\
\hline
\end{tabular}

Based on Table 4, ownership concentration affects the total risk of the bank. The bank's total risk proxy is measured by the daily bank's standard deviation of returns. Therefore, the market is very determining this proxy. From the regression results, the concentration of ownership has a positive effect on risk with a value (4.933365). This means, if the ownership concentration is high (more concentrated) then the risk of the bank will also be high, and vice versa. Research conducted by Chun et al., (2011) and Laeven \& Levine, (2009) as cited in Ahmad (2013) found that concentration of ownership had a positive effect on risk-taking. According to Kim et al., (2007) as cited in Saggese \& Sarto (2016), this is due to the weak monitoring factor because the owners are concentrated in one group only.

Also, Table 4 explains the effect of foreign and domestic ownership on risk. Table 4 shows that foreign ownership has a positive effect on risks. This means, the higher the foreign ownership in a bank, the higher the risks. Risks are in line with the type of ownership. So that banks or foreign ownership have risks in Indonesia, considering that foreign ownership will experience twice adjustments. Twice adjustments can be attributed to the risk of work culture and social differences. Ownership of a bank controlled by a foreign person or group will implement a culture and work system that is different from the social and cultural conditions in Indonesia. Based on the results and research data, foreign ownership will experience difficulties in communicating and transferring knowledge with banking workers in Indonesia. Foreign ownership will make adjustments socio-cultural first. Other risks, this study found the influence of the global and sectoral economic crisis. As experienced by Indonesian banks in 1998 and

Copyright (C) 2020. Owned by Author(s), published by Society. This is an open-access article under the CC-BY-NC-SA license. https://doi.org/10.33019/society.v8i1.152 
2008. Initially, the crisis that occurred was a global financial crisis, but the crisis spread and worsened, becoming sectoral crises in Indonesia such as political and social crises. Indonesia was the hardest hit by the crisis, not only having an impact on the economy but also having a significant and overall impact on the political system and social conditions in Indonesia. Companies in Indonesia (including banks) suffered huge losses. Foreign exchange supply is scarce because new loans for companies in Indonesia are not provided by foreign creditors. Many foreign creditors withdrew their funds abroad because they were worried that economic, political and social conditions in Indonesia were not conducive. The number of poor people in Indonesia, at the time of the crisis in 1998, reached 49.5 million (around $24.20 \%$ of the population of Indonesia), the worst in the history of Indonesia (Badan Pusat Statistik, 2018).

\section{Conclusions}

This research examined the effect of concentration and type of ownership both foreign and domestic on banking performance and risks. This research sought to find variables that affect banking performance and risks. The results of the research showed that there was no effect of ownership concentration on performance. Also, the results of the research showed the positive effect of domestic ownership on bank performance. This research found that there is still a traumatic influence from the 1998 monetary economic crisis. The crisis caused the economic collapse, political and social turmoil, and all sectors. Many foreign creditors, which still hold their funds abroad, are afraid to invest in Indonesia. Therefore, this research has assessed the fair results obtained. Domestic ownership has a positive effect on the performance of Indonesian banks in general.

Also, in terms of risks, ownership concentration has a positive effect on risks. The more concentrated ownership, the more banks at risk. This strongly supports the condition of the Indonesian banking sector during the crisis in 1998. The funds in Indonesia are controlled by a few people and are concentrated. When economic, social and political conditions are not secure, creditors can withdraw funds from Indonesia. Therefore, the results of the research conducted showed that there is still a positive relationship between concentration and risks. Foreign and domestic ownership affects risks. Foreign ownership has a positive effect on risks. This is in line with the findings of research on the effects of the traumatic crisis of 1998. The results showed that the higher the foreign ownership, the more banks at risk.

\section{Acknowledgment}

The authors would like to thank Tidar University and University of Bangka Belitung for their support and facilities in this research. The author also wishes to thanks 2 anonymous reviewers for their input, suggestions, and corrections during the review process of this article.

\section{References}

Ahmad, F. (2013). Ownership Structure and Non-Performing Loans: Evidence from Pakistan. Asian Journal of Finance $\mathcal{E}$ Accounting, 5(2), 268-288. https:/ / doi.org/10.5296/ajfa.v5i2.4133

Al-Amarneh, A. (2014). Corporate Governance, Ownership Structure and Bank Performance in Jordan. International Journal of Economics and Finance, 6(6). https:/ / doi.org/10.5539/ijef.v6n6p192

Anggraini, A., Yohan, Y., \& Gurendrawati, E. (2015). Firm Size, Ownership Concentration and Business Sector: The Influence to Credit access SMEs in Indonesia. International Journal of

Copyright ( ) 2020. Owned by Author(s), published by Society. This is an open-access article under the CC-BY-NC-SA license. https://doi.org/10.33019/society.v8i1.152 
The Determination of Concentration and Type of Ownership on Bank Performance and Risks in Indonesia

Finance Accounting,
http://article.sapub.org/10.5923.j.ijfa.20150405.01.html

4(5): 231-235.

Badan Pusat Statistik. (2014, 130). Jumlah Penduduk Miskin, Persentase Penduduk Miskin dan Garis Kemiskinan, 1970-2017. Retrieved from Badan Pusat Statistik Republik Indonesia: https:/ / www.bps.go.id/statictable/2014/01/30/1494/jumlah-penduduk-miskinpersentase-penduduk-miskin-dan-garis-kemiskinan-1970-2017.html

Bank Indonesia. (2007). Sejarah Bank Indonesia: Perbankan. Jakarta: Unit Khusus Museum Bank Indonesia.

Barth, J. R., Caprio, G., \& Levine, R. (2000). Banking systems around the globe : do regulation and ownership affect the performance and stability? (English). Policy, Research Working Paper (WPS2325). Washington, DC: World Bank. http:/ / documents.worldbank.org/curated/en/295671468779405439/Banking-systemsaround-the-globe-do-regulation-and-ownership-affect-the-performance-and-stability

Boussaada, R., \& Karmani, M. (2015). Ownership Concentration and Bank Performance: Evidence from MENA Banks. International Journal of Business and Management, 10(3). https://doi.org/10.5539/ijbm.v10n3p189

Céspedes, J., González, M., \& Molina, C. A. (2010). Ownership and capital structure in Latin America. Journal of Business Research, 63(3), 248-254. https:// doi.org/10.1016/j.jbusres.2009.03.010

Chun, S. E., Nagano, M., \& Lee, M. H. (2011). Ownership Structure and Risk-taking Behavior: Evidence from Banks in Korea and Japan. Asian Economic Journal, 25(2), 151-175. https://doi.org/10.1111/j.1467-8381.2011.02056.x

Dalkır, E., Dalkır, M., \& Levit, D. (2019). Freeze-out mergers. The Review of Financial Studies, 32(8), 3266-3297. https:/ / doi.org/10.1093/rfs/hhy102

Demirhan, D. (2013). Effects of the recent financial crisis on the determinants of bank profitability: Case of Turkish banking industry. Journal of Yaşar University, 8(31) 5203-5228. http:// dergipark.org.tr/en/pub/jyasar/issue/19143/203134

Dewayanto, T. (2010). Pengaruh mekanisme good corporate governance terhadap kinerja perbankan nasional. Fokus Ekonomi: Jurnal Ilmiah Ekonomi, 5(2), 104-123. https://ejournal.stiepena.ac.id/index.php/fe/article/view/62

Hadad, M. D., Sugiarto, A., Purwanti, W., Hermanto, M. J., \& Arianto, B. (2004, 9 8). Kajian Mengenai Struktur Kepemilikan Bank di Indonesia. Retrieved from Bank Indonesia: https://www.bi.go.id/id/publikasi/perbankan-danstabilitas/riset/Pages/Kajian\%20Mengenai\%20Struktur\%20Kepemilikan\%20Bank.aspx

Hintošová, A., \& Kubíková, Z. (2016). The effect of the degree of foreign ownership on firms' performance, Review of Economic Perspectives, 16(1), 29-44. https:/ / doi.org/10.1515/revecp2016-0003

Imam, M. O., \& Malik, M. (2007). Firm Performance and Corporate Governance Through Ownership Structure: Evidence from Bangladesh Stock Market. International Review of Business Research Papers, 3(4), 88-110.

Nguyen, P. (2012). The impact of foreign investors on the risk-taking of Japanese firms. Journal of the Japanese and International Economies, 26(2), 233-248. https:/ / doi.org/10.1016/j.jjie.2012.03.001

Niu, J. (2012). An empirical analysis of the relation between bank charter value and risk taking. Quarterly Review of Economics and Finance, 52(3), 298-304. https://doi.org/10.1016/j.qref.2012.05.001 
Paligorova, T. (2010). Corporate Risk Taking and Ownership Structure. Bank of Canada Working Paper Series. Ottawa: Bank of Canada. https://www.banqueducanada.ca/wpcontent/uploads/2010/05/wp10-3.pdf

Pathan, S. (2009). Strong boards, CEO power and bank risk-taking. Journal of Banking and Finance, 33(7), 1340-1350. https:// doi.org/10.1016/j.jbankfin.2009.02.001

Pham, P. K., Kalev, P. S., \& Steen, A. B. (2003). Underpricing, stock allocation, ownership structure and post-listing liquidity of newly listed firms. Journal of Banking and Finance, 27(5), 919-947. https:/ / doi.org/10.1016/S0378-4266(02)00241-8

Phung, G., \& Tröge, M. (2018). Can Foreigners Improve the Profitability of Emerging Market Banks? Evidence from the Vietnamese Strategic Partner Program. Emerging Markets Finance and Trade, 54(7), 1672-1685. https://doi.org/10.1080/1540496X.2017.1318055

Saggese, S., \& Sarto, F. (2016). Disproportional Ownership Devices: Reviewing the Last 25 Years of Research. International Journal of Business and Management, 11(4), 22-36. https:/ / doi.org/10.5539/ijbm.v11n4p22

Satya, V. E. (2007). Pengaruh Struktur Kepemilikan Terhadap Kinerja Perusahaan: Studi Empiris pada Perusahaan Go Public di Indonesia (Thesis). Yogyakarta: Universitas Gadjah Mada. http://etd.repository.ugm.ac.id/home/detail_pencarian/36783

\section{About the Authors}

1. Yacobo P Sijabat, obtained his Magister Degree in Management from Gadjah Mada University, Yogyakarta, Indonesia, in 2017. The author is an Assistant Professor at the Department of Management, Faculty of Economics, Tidar University, Indonesia.

E-Mail: yacobo.djabat@untidar.ac.id

2. Michael Jeffri Sinabutar, obtained his Magister Degree in Sociology from Gadjah Mada University, Yogyakarta, Indonesia, in 2018. The author is an Assistant Professor at the Department of Sociology, Faculty of Social and Political Sciences, University of Bangka Belitung, Indonesia.

E-Mail: jeffrisinabutar@gmail.com

3. Heni Hirawati, obtained her Magister Degree in Management from Islamic University of Indonesia, Yogyakarta, Indonesia, in 2015. The author is an Assistant Professor at the Department of Management, Faculty of Economics, Tidar University, Indonesia.

E-Mail: heni.hirawati@untidar.ac.id

4. Axel Giovanni, obtained his Magister Degree in Management from Diponegoro University, Semarang, Indonesia, in 2018. The author is an Assistant Professor at the Department of Management, Faculty of Economics, Tidar University, Indonesia.

E-Mail: axelgiovanni@untidar.ac.id 